\title{
The Use of Madrasah E-Learning for Online Learning during the Covid-19 Pandemic
}

\author{
Haris Firmansyah 1 , Fandri Minandar ${ }^{2}$
}

DOI: 10.35445/alishlah.v13i1. 503

\begin{tabular}{l} 
Article Info \\
\hline Keywords: \\
Madrasah E-Learning \\
Planning \\
Implementation \\
Evaluation
\end{tabular}

Kata kunci:

E-learning Madrasah

Perencanaan

Pelaksanaan

Evaluasi

\begin{abstract}
The purpose of this study is to find out how to use Madrasah E-Learning in online learning during the Covid-19 pandemic by looking at three important aspects, including planning, implementation and evaluation. This study uses a qualitative research approach with descriptive methods. This type of qualitative research used is basic research. At the same time, the data collection techniques are through observation, interviews and documentation. Observations were made at Madrasah Aliyah Negeri 1 Pontianak. The results of this study are: (1) Madrasah e-learning will automatically store the planning data that the teacher compiles, and if it is needed to be printed, the teacher can print directly with the existing menu. (2) Implementation of learning during the COVID-19 pandemic, Madrasah e-learning is equipped with a video convergence menu, teachers and students can conduct virtual meetings. Students can also read the material provided in the teaching materials menu. And (3) Evaluation of E-learning Madrasah learning provides menus for conducting assessments. Cognitive assessment can be done in multiple-choice, essay, true-false, jump, which can be done in the Computer Based Test (CBT) menu.
\end{abstract}

\begin{abstract}
Abstrak
Tujuan penelitian ini adalah untuk mengetahui bagaimana penggunaan ELearning Madrasah dalam pemebalajaran daring pada masa pandemi covid19 dengan melihat tiga aspek penting antara lain perencanaan, pelaksaan dan evaluasi. Penelitian ini menggunakan pendekatan penelitian kualitatif dengan metode deskriptif. Jenis Penelitian kualitatif yang digunakan yakni penelitian dasar (basic research). Adapun teknik pengumpulan data melalui observasi, wawancara dan dokumentasi. Observasi dilakukan di Madrasah Aliyah Negeri 1 Pontianak. Hasil penelitian menunjukkan bahwa : (1) E-learning Madrasah secara otomatis akan menyimpan data-data perencanaan yang guru susun, dan jika diperlukan untuk dicetak, guru dapat langsung mencetak dengan menu yang ada. (2) Pelaksanaan pemebelajaran masa pandemi covid-19, Elearning Madrasah dilengkapi dengan menu video converensi, guru dan siswa dapat melakukan pertemuan virtual. Siswa juga dapat membaca materi yang diberikan dimenu bahan ajar. Dan (3) Evaluasi pembelajaran E-learning Madrasah menyediakan menu-menu untuk melakukan penilaiaan. Penilaiaan kognitif dapat dilakukan dalam bentuk pilihan ganda, essay, benar salah, menconcokkan yang dapat dilakukan di menu Computer Base Tes (CBT).
\end{abstract}

\footnotetext{
${ }^{1}$ Universitas Tanjungpura, Pontianak, Indonesia

Email: harisfirmansyah@untan.ac.id

2 Madrasah Aliyah Negeri 1, Pontianak, Indonesia

Email: fandriminandar@gmail.com
} 


\section{PENDAHULUAN}

Isu Covid-19 yang mulai muncul pada penghujung tahun 2019 di Cina tepatnya di kota Wuhan ini pada awal tahun tahun 2020 kemudian menjadi isu international. Hal ini karena penyebaran Covid-19 menyebar pesat di seluruh dunia. Sehingga WHO sebagai organisasi Kesehatan dunia menyebut Virus Covid-19 merupakan suatu pandemi. Berdasarkan data WHO sampai pada tanggal 2 maret 2020 total yang terinveksi Covid-19 berjumlah 90.308, untuk di Indonesia sendiri pada awal tahun 2020 tersebut mengumumkan ada 2 orang yang terinfeksi. Angka kematian yang terinfeksi sampai pada angka 3.087 atau 2.3\% dengan angka kesembuhan 45.726 orang (Yuliana, 2020).

Virus Covid-19 yang juga dikenal dengan istilah Coronovirus 2019 ini tidak berimbas hanya pada bidang kesehatan dan bidang ekonomi saja namun juga berimbas pada aspek sosial, budaya, agama dan tentunya juga berdampak pada bidang pendidikan (Boca et al., 2020). Pemerintah Indonesia segera mengambil kebijakan dalam upaya mencagah penyebaran virus Covid-19, kebijakan yang diambil yakni melakukan pembatasan pada berbagai aktivitas masyarakat. Di wilayah Indonesia lainnya, pemerintah daerah juga berperan andil guna meghentikan lajunya penyebaran virus. Kementerian pendidikan dan budaya dalam merespon kebijakan tersebut segera mengeluarkan regulasi terkait pola pendidikan baik di sekolah maupun di perguruan tinggi yang biasanya dilangsungkan secara muka dijadikan pembelajaran dalam jaringan yang biasanya dikenal dengan istilah pembelajaran jarak jauh (Mustajab et al., 2020).

Kekhawatiran mulai muncul dalam pemikiran pemimpin pendidikan pada awal covid-19 jika sekolah tidak masuk dalam waktu yang cukup lama akan berdampak pada prestasi siswa yang akan menurun serta anjloknya kemampuan akademis siswa (Kuhfeld et al., 2020b). Ditutupnya sekolah dalam waktu yang cukup panjang akibat dari pandemic covid-19 ini dampaknya akan sulit diperkirakan (Kuhfeld et al., 2020a).

Dunia pendidikan, melalui kebijakan menteri pendidikan, memerintahkan seluruh instansi pendidikan untuk melaksanakan pembelajaran dengan menerapkan pshical distancing dengan memanfaatkan media pembelajaran jarak jauh. Pembelajaran dalam jaringan dapat dilaksanakan dari mana saja dengan bantuan internet yang dapat diakses melalui komputer, laptop, maupun Handphone (Putria et al., 2020). Kehadiran guru untuk mengajar juga berkaitan bagaimana lingkungan belajar dirancang dan difasilitasi untuk saling mendukung (Edmunds et al., 2021). Oleh sebab itu guru dan siswa dituntut untuk merancang dan memanfatkan fasilitas media internet dengan penuh ketelitian serta kejelian saat menyampaikan dan menerima informasi yang akan disampaikan.

Berbagai macam media pembelajaran daring yang dapat digunakan oleh sekolah untuk tetap menjalankan amanah pendidikan di Indonesia aplikasi yang sering digunakan dalam pembelajaran daring yaitu whatsapp, geogle calsroom, sosial media, dan lainnya (Rigianti, 2020). Di lingkungan Madrasah sendiri, sudah diberikan sebuah aplikasi untuk pembelajaran daring yang disebut dengan E-learning Madrasah. E-learning Madrasah merupakan infastruktur pembelajaran untuk membantu dalam dunia pendidikan agar tetap berjalan lancar, terutama saat pandemic Covid-19 yang (Sutini et al., 2020). Insiyah (2020) mengatakan E-learning Madrasah yang digagas oleh Kementerian Agama ini merupakan aplikasi yang dapat digunakan secara gratis oleh guru dan siswa dengan mengunjungi web https://elearning.kemenag.go.id/web. E-Learning Madrasah ini dirancang agar pembelajaran yang dilakasankan secara daring ini bias terstruktur, menarik, dan interaktif.

E-Learning sebenarnya sudah lama dikenal sejak penggunaan internet dijadikan sebagai media pembelajaran (Puška et al., 2021). Namun penggunaan E-Learning semakian popular ketika masa pandemic covid-19 ini. Lahirnya aplikasi E-learning Madrasah diresmikan diawal tahun 2020 yang dapat memberikan manfaat dalam pembelajaran daring (Hikmah, 2020). E-learning Madrasah 
sebagai media pembelajaran jenjang pendidikan dibawah kementerian agama yaitu Madrasah Ibtidaiyah (MI), Madrasah Tsanawiah (MTs), dan Madrasah Aliah (MA). E-learning ini dapat menjadi solusi dalam pembelajaran daring di masa pandemi ini, bahkan jika kelak suatu saat telah normal kembali, E-Learning dapat dijadikan media pembelajaran yang dapat mempermudah akses pembelajaran seperti mengunduh bahan ajar, RPP, materi, dan untuk melaksanakan evaluasi.

Pada kondisi dan situasi pandemic seperti saat ini, pembelajaran berbasis E-learning menjadi bagian penting dalam satuan pendidikan baik lembaga publik maupun lembaga pendidikan Islam (Fauzi et al., 2018). Chien (2012) dalam hasil penelitiannya menyebutkan sejak E-learning diperkenalkan ke dalam dunia pendidikan, peran guru mulai berubah. Kemajuan teknologi yang menyebabkan perubahan yang sangat signifikan dalam dunia pendidikan. E-learning akan berhasil dilaksanakan jika didukung dengan pelatihan dan infrastruktur teknologi yang memadai. Pada saat ini E-learning dapat digunakan dengan berbagai macam fungsinya, E-learning memiliki dua jenis yakni synchronous dan asynchronous. Sehingga dalam pembelajaran menggunakan E-learning, proses pembelajaran bisa dilaksanakan dalam waktu bersamaan antara guru dan peserta didik dan bisa juga tidak bersamaan namun dapat diatur waktunya (Munif et al., 2021). Penelitian Muali et al. (2018) menyebutkan bahwa pembelajaran online yang dilakukan secara mandiri dapat diterapkan dengan konsep belajar mandiri online berbasis Rich Internet Applications (RAI) dapat dijadikan alternatif model pembelajaran dengan konsep mengembangkan persta didik agar dapat lebih berpikir kritis. Adanya E-learning Madrasah menyebabkan pembelajaran dapat lebih terstruktur dan interaktif, sehingga pembelajaran daring lebih efektif. E-learning Madrasah memiliki 6 role akses yaitu operator, guru, bimbingan konseling, wali kelas, siswa, dan suvervisor (kepala madarasah, pengawas dan jajaran lainnya) (Sutini et al., 2020). Dengan demikian aktifitas pembelajaran dapat dilihat rekam jejaknya dalam E-learning Madrasah yang dapat diakses operator madrasah. E-learning Madarasah dapat membantu pembelajaran daring demi tetap tercapainya tujuan pendidikan, sebagaimana pembelajaran yang dilakukan pada saat situasi normal.

Pembelajaran pada masa pandemic yang dilaksakan secara dari ini pastinya memberikan warna baru dalam dunia pendidikan. Sebagai penggerak di dunia pendidikan, baik guru mau pun siswa, dituntut untuk dapat menyesuaikan diri dengan teknologi yang digunakan. Agar tujuan pendidikan tetap tercapai sesuai target yang diharapkan. Namun, hal demikian tidak lah berjalan lancar. Dengan suasana baru dalam pembelajaran, pastinya ditemukan hal-hal baru yang menjadi kendala dalam pembelajaran. Tidak hanya yang dirasakan guru dan peserta didik namun juga dirasakan dan diresahkan orang tua.

Terdapat beberapa faktor yang mempengaruhi pembelajaran daring. Jaringan internet menjadi peran utama dalam pembelajaran daring, namun bagi wilayah yang berada di pedalaman akan sulit untuk mendapatkan jaringan, sehingga ini menjadi pekerjaan rumah terbesar bagi pemerintah terutama dapam dunia pendidikan untuk tetap menjalankan pembelajaran daring (Insiyah, 2020). Perekonomian masyarakat saat ini juga perlu menjadi sorotan penting, hal ini dikarenakan penyediaan kuota internet, penyedian handphone android ataupun laptop perlu biaya yang cukup besar. Tanpa ada media dan kuota internet, pembelajaran daring tidak akan bisa dilaksanakan. Bagi orangtua yang memiliki pekerjaan tetap dan berpenghasilan tetap mungkin dapan menghadapi maslah tersebut, namun sebaliknya bagi yang orangtua mengalami ekonomi sulit, pastinya akan berdampak kepada pembelajaran kepada anaknya untuk pembelajaran daring.

Madrasah Aliah Negeri 1 Pontianak (MAN 1 Pontianak) menerapkan E-learning Madrasah sejak awal ajaran baru 2020/2021. Kepala Madrasah mengintruksikan kepada guru sesuai dengan amanah dari Kabid Madrasah Kanwil Provinsi Kalimantan Barat dan Dirjen Pendis Kementerian Agama untuk memanfaatkan E-leraning Madrasah sebagai media yang dapat digunakan selama masa pandemic covid-19 dan tentu saja harapan setelah pandemi ini berlalu E-learning Madrasah tetap dapat digunakan sebagai media online dalam pembelajaran tatap muka. Untuk mengahadapai pembelajaran daring, maka guru harus dibekali terlebih dahulu dalam penggunaan aplikasi E- 
learning Madrasah ini. Tidak hanya guru, E-learning Madarasah juga disosialisaikan kepada siswa agar pembelajran tetap berlangsung.

Pelaksanaan E-Learning Madrasah di Madrasah Aliyah Negeri 1 Pontianak sendiri tentu masih banyak mengalami kendala baik yang dihadapi oleh guru maupun siswa. kendala dalam pelaksanaan pembelajaran melalui E-learning Madrasah diantaranya: Pertama, aplikasi E-learning Madrasah yang digunakan hampir di seluruh madrasah menjadikan terkadang sangat sulit diakses oleh guru maupun siswa. Kedua, jaringan internet yang tidak stabil dan kuota belajar. Ketiga, media yang digunakan siswa hampir menggunakan handphone yang kapasistas Ram kecil sehingga mempengaruhi untuk mengakses dan menyimpan bahan ajar. Keempat, kunjungan guru melalui homevisit banyak siswa yang hanya absensi saja saat belajar, dampaknya tugas-tugas yang diberikan banyak tidak dikerjakan.

Ada beberapa penelitian yang telah mengkaji tentang E-Learning Madrasah. Pertama penelitian yang dilakukan oleh Insiyah (2020) dengan hasil penelitiannya mendeskripskian dengan menggunakan E-Learning Madrasah pembelajaran daring menjadi lebih efektif dibandingkan dengan pembelajaran tatap muka, namun pembelajaran daring ini tergantung dengan kuota jaringan yang dimiliki guru dan siswa. Yang kedua Penelitian Hikmah (2020) dengan hasil penelitiannya mendeskripsikan aplikasi E-learning Madrasah sangat membantu serta bermanfaat dalam menunjang pembelajaran di masa Pandemi Covid-19. Penelitian ini memiliki perbedaan dengan dua hasil penelitian tersebut adalah analisis dan deskripsi yang akan dilakukan adalah bagaimana pelaksanaan secara menyeluruh dalam penggunaan aplikasi E-Learning Madrasah ini pada tiga aspek penting dalam pembelajaran yakni perencanaan, pelaksanaan dan evaluasi.

Tujuan dalam penelitian ini yang menjadi fokus penelitiannya yaitu untuk mengetahui bagaimana penggunaan E-Learning Madrasah dalam pembelajaran daring pada masa pandemi covid-19 dengan melihat tiga aspek penting sebagimana yang telah disebutkan sebelumnya anatara lain perencanaan, pelaksaan dan evaluasi.

\section{METODE PENELITIAN}

Pendekatan yang digunakan dalam penelitian ini adalah penelitian kualitatif. Kualitatif sebagai metode penelitian yang berlandaskan filsafat postpositivisme dimana posisi peneliti menjadi instrument penting dalam meneliti obyek yang diteliti (Moleong, 2017). Jenis Penelitian kualitatif yang digunakan yakni penelitian dasar (basic research).

Untuk mendapatkan gambaran secara mendalam terkait penggunaan E-Learning Madrasah dalam pembelajaran daring pada masa covid-19 yang dilaksanakan di Madrasah Aliyah Negeri 1 Pontianak maka metode yang digunakan dalam penelitian ini adalah metode deskriptif. Metode deskriptif dapat diartikan sebagai prosedur pemecahan masalah yang diselidiki dengan melukiskan keadaan subjek/obyek penelitian berdasarkan fakta-fakta yang tampak atau sebagaimana adanya (Nawawi, 2007). Pelaksanaan penelitian ini dilakukan pada semester genap tahun ajaran 2020/2021 pada kelas X Madrasah Aliyah Negeri 1 Pontianak.

Sumber data yang digunakan peneliti yaitu sumber primer yang diperoleh melalui 1) Observasi langsung yang bersifat partisipasi pasif maupun aktif yang mana peneliti dapat mengamati objek penelitian. Selanjutnya melakukan observasi langsung terhadap sumber data untuk mendukung dalam pencarian data, 2) Wawancara mendalam (indepth interview), dilakukan dengan menggunakan bentuk dialog antara peneliti dan informan dalam kondisi tertentu. Untuk itu diperlukan pedoman wawancara (interview guide) agar wawancara lebih mendalam dan terarah; dan (3) Mengkaji dokumen dan arsip (content analysis) tentang pengunaan E-Learing Madrasah dalam pembelajaran daring pada masa pandemic covid-19.

Adapun teknik pengumpulan data melalui observasi, wawancara dan dokumentasi. Observasi dilakukan di Madrasah Aliyah Negeri 1 Pontianak. Sedangkan wawancara dilakukan pada kepala sekolah, waka kurikulum, guru dan peserta didik yang menggunakan e-leraning madrasah dalam pemebalajaran daring. 
Penelitian ini bersifat deskriptif-kualitatif dengan teknik analisis interaktif (Miles \& Huberman, 1984). Teknik analisis interaktif dari tiga komponen analisis yang digunakan yakni meliputi reduksi data, sajian data dan penarikan kesimpulan atau verifikasi. Sedangkan untuk pengujian keabsahan data penelitian menggunakan triangulasi sumber, triangulasi teknik pengumpulan data.

\section{HASIL PENELITIAN DAN PEMBAHASAN}

\section{Perencanaan Pembelajaran Menggunakan E-learning Madrasah Dalam Pembelajaran Daring}

Hanum (2013) dalam hasil penelitiannya mengemukakan bahwa dalam pembelajaran menggunakan E-Learning pada aspek perencanaan pembelajaran masuk dalam katagori cukup efektif yakni dengan persentase tingkat kecenderungan sebesar 77,57\%. Perencanaan pembelajaran merupakan salah satu indikator yang mempengaruhi keberhasian seorang guru mengajar.

Sebagai seorang guru yang bertugas menyampaikan materi dan informasi dalam proses pembelajaran, wajib sebelumnya untuk menyusun suatu perencanaan pembelajaran. Adanya perencanaan pembelajaran ini guna membantu guru dalam mengajar sehingga pembalajaran terlaksana secara sistematis serta efisien. Perencanaan pembelajaran dapat memuat bahasan yang akan disajikan dalam satu pertemuan maupun beberapa pertemuan yang berfungsi sebagai acuan guru dalam pembelajaran (Ananda, 2019).

Dalam penyusunan perencanaan terdapat komponen yang wajib dituliskan harus mengacu pada silabus yang ada. Komponen utama dalam penyusunan perencanaan pembelajaran meliputi kompetensi dasar, kompetensi inti, indikator, tujuan pembelajaran, kegiatan inti, dan evaluasi (Mazid \& Suharno, 2019). Komponen-komponen tersebut dapat dikembangkan oleh guru sesuai dengan bidang disiplin keilmuannya. Namun dimulai tahun 2019 Menteri pendidikan telah menyederhanakan sebuah perencanaan pembelajaran yang menjadi tiga komponen utama, yaitu kompetensi dasar, kegiatan pembelajaran, dan assasmen/evaluasi pembelajaran. Perencanaan pembelajaran tersebut menjadi lebih sederhana namun lebih tertuju pada inti dari perencanaan.

Perencanaan pembelajaran memiliki tujuan untuk menunjukkan perencanaan, pengembangan, penilaian dan pengolaan proses pembelajaran (Anggraeni \& Akbar, 2018). Dengan demikian perencanaan pembelajaran menjadikan suatu hal yang wajib disusun oleh guru sebelum melakukan proses pembelajaran yang akan dilaksanakan.

Dalama pembelajaran daring di MAN 1 Pontianak, setiap guru menyusun perencanaan sebelum pembelajaran daring dimulai. Silabus yang digunakan di masa pandemi covid-19 ini adalah kurikulum darurat yang telah dikeluarkan oleh kementerian pendidikan dan kebudayaan. Adanya E-learning Madrasah, membantu guru dalam menyusun perencanaan. Menu Perencanaan di Elearning Madrasah guru dapat mengisi langsung sesuai item-item yang disediakan. Namun sebelumnya guru harus mengisi terlebih dahulu Kompetensi dasar dan Indikator di menu Kompetensi dasar. Jika sudah tersisi maka data tersebut langsung tersingkron ke menu perencanaan. RPP yang susun oleh guru dapat disesuaikan dengan jumlah pertemuan dalam satu semester.

Di menu perencanaan dalam E-learning Madrasah, komponen-komponen memuat antara lain waktu, pertemuan ke-, bahasan materi, kompetensi inti, kompetensi dasar, tujuan pembelajaran, metode pembelajaran, media/sumber belajar, kegiatan pembelajaran, dan penilaiaan. Guru wajib mengisi komponen-komponen tersebut sesuai dengan kebutuhannya. Komponen Waktu terdiri tanggal pembuatan perencanaan dan jam ke-s/d jam ke- pelajaran dikelas yang akan diajar. Komponen Pertemuan Ke- diisi sesuai dengan pertemuan saat guru mengajar. Jika dibuat untuk pertemuan ke 2, maka diisi pertemuan ke 2. Komponen bahasan materi memuat materi yang akan dibahas pada pertemuan tersebut. Komponen Kompetensi Inti secara otomatis dapat dipilih jika di menu standar kompetensi sudah diisi sebelumnya. Komponen Kompotensi dasar juga secara otomatis dapat dipilih jika di menu standar kompetensi sudah terisi. Komponen tujuan diisi 
seuai dengan tujuan pembelajaran yang disusun. komponen metode pembelajaran memuat berkaitan dengan metode guru saat mengajar. Komponen media/sumber diisi alat apa dan sumber apa saja yang digunakan guru untuk mengajar. Komponen kegiatan pembelajaran meliputi kegiatan awal, kegiatan inti, dan kegiatan penutup. Terakhir adalah komponen penilaiaan yang memuat penialaian kognitif, psikomotorik, dan afektif.

Kepala Madarasah MAN 1 Pontianak mengatakan E-learning Madrasah sangat membantu guru dalam menyusun perangkatnya, sehingga guru tidak perlu lagi membuat perencanaannya secara manual di aplikasi word. Setelah diisi menu perencanaan, secara otomatis akan tersimpan di E-learning Madrasah, dan guru dapat mengprint/mencetak perencanaannya untuk disahkan oleh guru dan kepala Madrasah dan mempermudah guru untuk mengarsipkan perangkat pembelajarannya. Pernyataan tersebut sesuai dengan yang disampaikan oleh salah satu guru yang dilakukan saat wawancara mengatakan E-learning Madrasah memberi kemudahan kepada guru dalam merancang perencanaan pembelajaran. E-learning madrasah menyediakan fitur yang sesuai dalam perencanaan, seperti tersedianya form perencanaan pembelajaran sehingga guru hanya mengisi form tersebut dan tersimpan secara otomatis. Form perencanaan pembelajaran dalam $E$ learning Madrasah dapat dilihat pada gambar 1 di bawah ini:

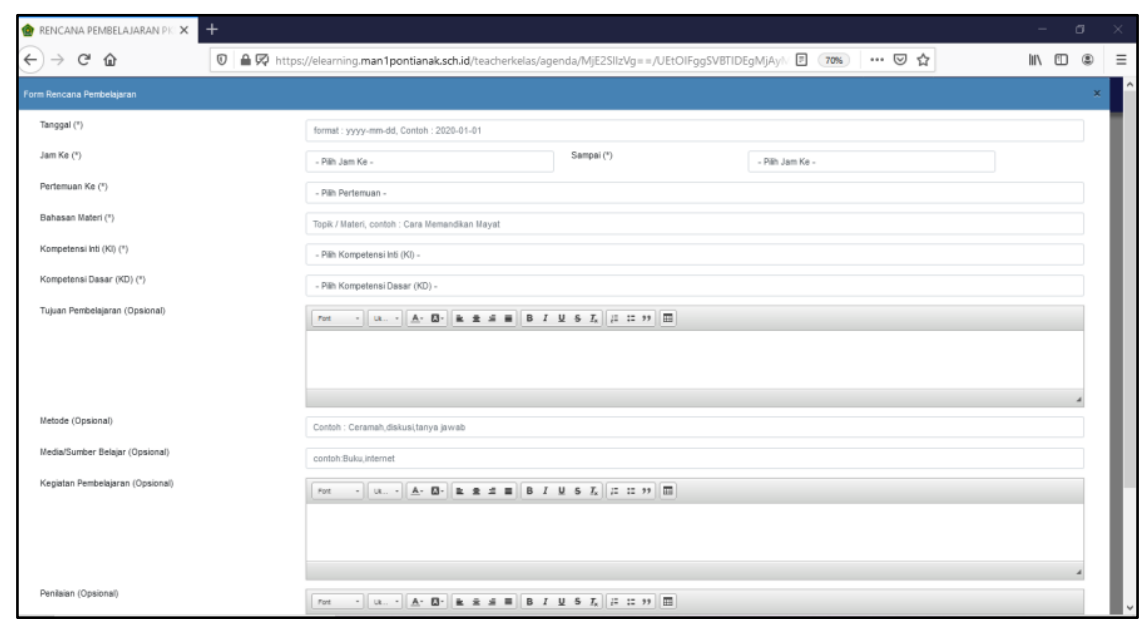

Gambar 1. Form pembelajaran E-learning Madrasah

\section{Pelaksanaan Pembelajaran Menggunakan E-learning Madrasah Dalam Pembelajaran Daring}

Hikmah (2020) dalam penelitiannya mengatakan bawah pembelajaran daring menggunakan E-Learning Madrasah yang dilakukan oleh guru serta siswa menunjukan arah postif dalam indikator pemanfaatan aplikasi tersebut, hal ini menunjukan adanya peningkatan penggunaan aplikasi $E$ Learning Madrasah selama masa pandemi covid-19. Pendidikan dalam siatuasi apapun tetap harus dilaksankan dan segara menyesuaikan diri dengan perkembangan zaman. Penggunaan E-Learning ini menunjukan bahwa pendidikan mengalami perubahan. Pendidikan di era abad 21 ini memilki peran penting dalam pembangunan nasional. Tuntutan pendidikan menjadi sangat penting untuk menciptakan peserta didik yang memiliki skil/ keterampilan belajar dan berinovasi, ketarampilan teknologi, dan memiliki keterampilan hidup (life skill) untuk kehidupan dimasyarakat (Andrian \& Rusman, 2019). Para peserta didik dibekali keterampilan untuk dijadikan manusia unggul yang siap bersaing dan berkompetisi. Dengan demikian pelaksanaan pembelajaran harus dilaksanakan semaksimal mungkin agar pengalam belajar peserta didik menjadi bermakna. Pengalaman belajar peserta didik ini disebut juga sebagai proses belajar, terdapat kegiatan interaksi antara guru dan siswa untuk mencapai tujuan pendidikan dan menghasilkan perubahan perilaku menjadikan pengalaman pribadinya (Putria et al., 2020). 
Pendekatan Saintific di era pembelajaran abad 21 menjadikan peserta didik untuk aktif mengkonstruk pengetahuannya baik secara konsep melalui tahapan-tahapan mengamati, menanya, mencoba/mengumpulkan informasi, mengasosiasi/menalar, dan mengkomunikasikan pengetahuannya (Persada et al., 2020). Tahapan tersebut harus ditampilkan dalam pembelajaran saat ini. Peran guru dalam pelaksanaan pembelajaran menjadi lebih tertantang dengan memanfaatkan media apa saja agar pembelajaran lebih menarik dan siswa mendapatkan pengalaman belajaranya.

Pembelajaran dapat dilaksanakan antara guru dan siswa yang memiliki aktifitas untuk mencapai suatu tujuan. Aktifitas antara guru dan siswa dapat berupa bimbingan, pengarahan siswa, menyampaikan informasi sesuai dengan bidang keilmuan. Terdapat interaksi timbal balik saat proses pembelajaran, baik antar satu arah maupun banyak arah. Pembelajaaran merupakan suatu aktifitas yang dilakukan oleh guru dan siswa berupa bentuk bimbingan, menyampaikan informasi, dan mengarahkan siswa untuk mendapatkan pengalaman belajar sesuai dengan tujuan yang direncanakan (Ananda, 2019).

Pembelajaran daring melahirkan kelas-kelas online yang variatif yang dapat diakses melalui jaringan internet, sehingga guru ataupun siswa dapat melakukan pembelajaran tidak dibatasi tempat dan waktu (Firman \& Rahayu, 2020). Kepala kanwil kemneag Kalbar memberikan kewenangan penuh kepada guru untuk melakukan berbagai media elektronik secara online untuk melaksanakan tugasnya. E-learning Madrasah menjadi aplikasi utama dalam pembelajaran, namun guru boleh menggunakan aplikasi lainnya seperti geogle classrom untuk pembelajaran. Di Madrasah, lahirnya E-learning Madrasah menjadi aplikasi utama untuk para guru melaksanakan pembelajaran daring. Guru dapat mengupload langsung bahan ajar yang telah disiapkannya. Guru juga dapat melihat apa saja aktivitas siswa di dalam sistem.. Untuk melakukan pembelajaran dengan video, guru dapat melakukan dengan menu converensi. Siswa juga dapat melakukan absensi secara individu, dan guru dapat melihat absensi siswa tersebut. Menu-menu yang ada di E-learning Madrasah sangat lengkap dan pastinya sangat membantu guru untuk digunakan dalam pembelajaran.

Proses pembelajaran di MAN 1 Pontianak lebih difokuskan dan diutamakan menggunakan $E$ learning Madrasah. Namun diperbolehkan juga untuk menggunakan aplikasi lainnya seperti geogle classroom, grub WA, telegram, facebook, instagram dan lain-lain agar pembelajaran dapat terlaksana. Pelaksanaan pembelajaran E-learning Madrasah sangat mudah diakses oleh guru maupun siswa. Guru dan siswa sebelumnya dibekali user dan password agar bisa masuk ke dalam E-learning Madarasah. Dashbord login E-Learning Madrasah tergambarkan pada gambar 2 berikut :

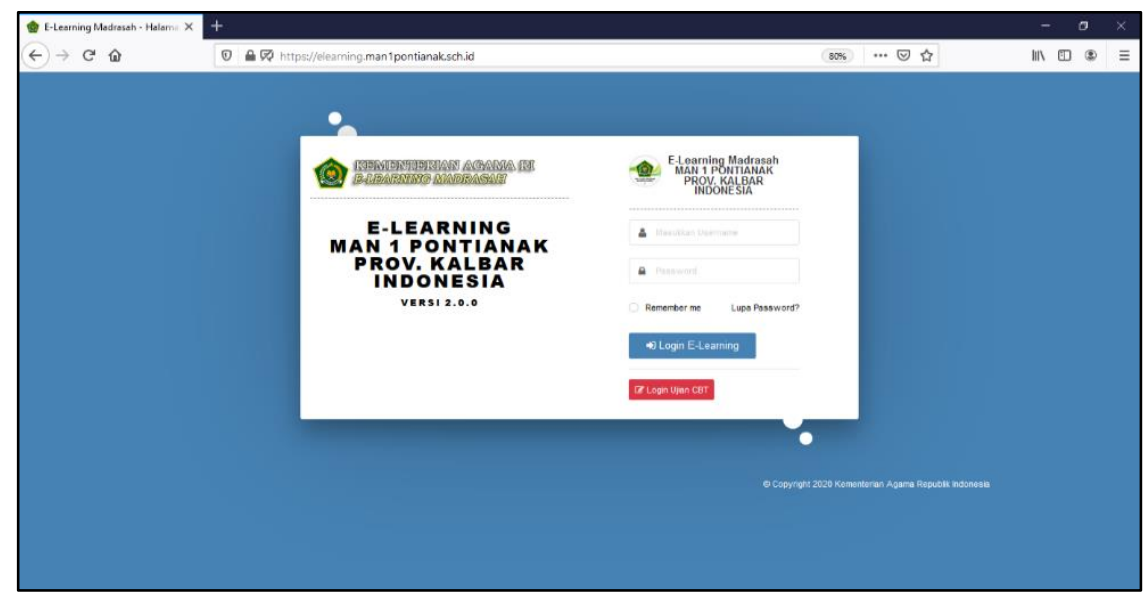

Gambar 2. Dashbord E-learning Madrasah

Wawancara yang dilakukan kepada guru yang mengajar mengatakan dalam pelaksanaan lebih efektif dibandingkan dengan media lain yang pernah digunakan sebelumnya. E-learning madrasah 
guru dapat langsung melihat aktifitas siswa yang secara langsung muncul di notifikasinya. Guru juga dapat melihat absensi siswa melalui fitur absensi kelas, siswa dapat melihat bahan ajar di menu bahan ajar, dan guru juga dapat melaksanan video conference. Contoh fitur absensi kelas bisa dilihat pada gambar 3 berikut ini :

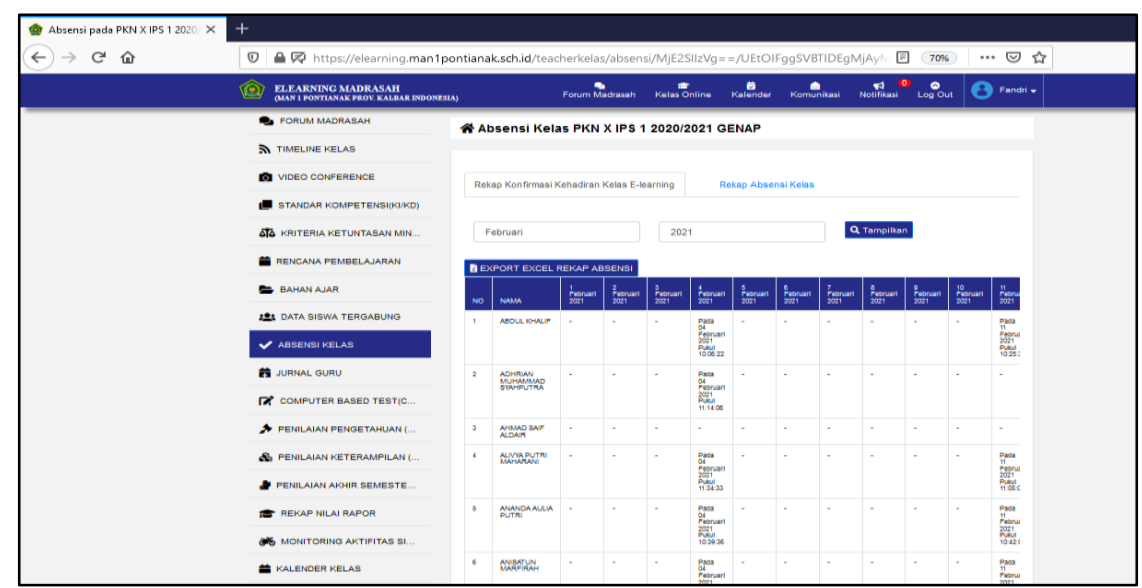

Gambar 3. Fitur absensi kelas E-learning Madrasah

Di akun guru, wajib membuat kelas online terlebih dahulu, dan mengundang siswa dalam kelas tersebut. Guru dapat mengupload bahan ajar menu bahan ajar baik dalam bentuk powerpoint, video, buku, dan lain-lain. Guru dapat melihat aktivitas siswa melalui menu notivikasi dan menu monitoring siswa. Selanjutnya jika guru ingin melakukan tatap muka terhadap siswa melalui video, guru dapat membuat jadwal yang sesuai dengan jadwal pelajarannya di menu Converence. Agar mempermudah interaksi Tanya jawab, guru dapat menulis petunjuk maupun arahan di timeline menu utama E-learning Madrasah.

Pada akun siswa yang telah diberikan user dan password E-learning Madrasah langsung masuk pada menu utama. Siswa yang telah diundang guru akan langsung otomatis masuk pada kelas pembelajarannya. Artinya setiap akun siswa akan memiliki kelas sesuai mata pelajarannya. Siswa langsung dapat memilih kelas mata pelajaran yang sedang berlangsung saat itu. Pertama, siswa harus melihat timeline yang dibagikan guru, agar mengetahui apa yang harus dilakukan saat pelajaran. Siswa dapat mendonlowd materi yang telah dibagikan ataupun dibuka secara online. Jika terdapat intruksi untuk melakukan video converence maka siswa langsung kemenu yang ada dan mengakses link yang telah dibuat oleh guru. Jika siswa ingin melakukan pertanyaan, siswa dapat berkomentar di timline yang guru bagikan.

Pembelajaran daring atau online ini pastinya memiliki temuan yang menjadi kendala saat proses pembelajaran berlangsung. Beberapa kendala yang ditemui pada saat pembelajaran online diantaranya jaringan internet, kuota belajar, media hendphone atau laptop yang tidak memadai, aplikasi yang terkadang gangguan (Rigianti, 2020). Jaringan internet adalah faktor utama dalam pembelajaran online, didaerah perdalaman terkadang jaringan internet sulit diakses oleh siswa, dan akan berdampak pada aplikasi yang digunakan menjadi tidak lancar. Bagi yang menggunakan wifi, kendala jaringan (gangguan) menjadi factor terhambatnya pembelajaran, sehingga siswa susah untuk mengakses pembelajaran. Dan yang tidak memiliki wifi, kuota menjadi faktor penting dalam mengakses internet. Biaya yang dikeluarkan saat pembelajaran daring cukup memakan biaya yang lumayan besar apalagi terdapat melakukan video conference (Sadikin \& Hamidah, 2020).

Kendala pembelajaran di MAN 1 Pontianak banyak sekali ditemukan. Hasil wawancara wakil kepala Madrasah bidang kurikulum mengatakan kendala yang sering ditemui saat pembelajan daring dengan E-learning Madrasah ini adalah Hosting yang hampir mencapai kapasitasnya, berdampak kepada kelancaran dari akses E-learning Mardasah itu sendiri baik guru maupaun pada siswa. Hasil wawancara yang dilakukan kepada guru, kendala dalam pelaksanaan pembelajaran 
yang ditemukan adalah lambatnya akses aplikasi E-learning Madrasah. Dan wawancara yang dilakukan kepada siswa bahwa kendala yang ditemukan saat pembelajaran daring melalui $E$ learning Madrasah adalah kuota internet yang terbatas, serta kapasitas RAM handphone yang sudah hampir mencapai kapasitasnya. Hal inilah yang membedakan kondisi belajar di rumah berbeda (baca: pembelajaran daring) antara satu siswa dengan siswa yang lainnya. contohnya akses ke perangkat teknologi yang akan berdampak pada kondisi belajar anak (Bonal \& González, 2020).

Perubahan suasana belajar dari yang tatap muka, menandai pembelajaran dalam jaringan ini memberikan kesan bagi guru, siswa dan orang tua. Hal demikian tidak lepas dari faktor pendukung dan penghambat dalam proses pembelajaran yang situasi baru ini. Dengan demikian perlu adanya evaluasi pada proses pembelajaran sehingga dapat diketahui apakah pembelajaran dapat berjalan dengan maksimal (Sutini et al., 2020).

\section{Evaluasi Pembelajaran Menggunakan E-learning Madrasah Dalam Pelajaran Daring}

Lubis et al. (2020) dalam hasil penelitiannya menyebutkan bahwa dalam pembelajaran daring menggunakan E-Learning evaluasi pembelajarannya berbasis pada kegiatan yang dilakukan oleh siswa, evaluasi tidak lagi hanya berorientasi pada hasil pembelajaran hal ini dikarenakan dalam sistem E-Learning guru tidak dapat menilai satu persatu secara menyeluruh perkembangan anak didiknya seperti yang dilakukan pada saat sebelum covid-19. Oleh sebab itu guru mengarahkan penilaiannya pada proses yang dilakukan oleh anak didiknya.

Tahap akhir dalam proses pembelajaran adalah evaluasi pembelajaran. Dalam pembelajaran daring juga perlu adanya evaluasi pembelajaran untuk melihat tujuan pembelajaran yang telah disusun dalam perencanaan. Evaluasi pembelajaran merupakan suatu proses dan berkelanjutan agar dapat melihat taraf tujuan yang dicapai berdasarkan pertimbangan dan kriteria yang telah dirancang (Setiawan, 2013).

Dalam evaluasi pembelajaran terdapat tiga aspek yang perlu dilihat yaitu kognitif, afektif, dan psikomotorik (Ratnawulan, 2014). Penilaiaan kognitif atau disebut juga penilaiaan pengetahuan, penilaiaan efektif yaitu penilaiaan sikap, dan penilaiaan psikomotorik disebut juga penilaiaan keterampilan. Dalam pembelajran kurikulum 13, ketiga aspek tersebut wajib untuk dilakukan penilaian diakhir dari proses pembelajran yang telah dilakukan.

Evaluasi menjadi suatu kegiatan yang sangat penting dilakukan untuk melihat hasil dari proses pembelajaran siswa yang digambarkan dengan tingkat kemampuan siswa memahami materi (Setemen, 2010). Ketercapaiaan tujuan pembelajaran dapat dilihat dari hasil ealuasi yang dilakuan oleh guru kepada siswanya setelah proses pemebelajaran dilaksanakan. Untuk melihat hasil dari proses pembelajran tersebut maka diperlukan alat untuk mengukur keberhasilan tersebut. Alat pengukuran tersebut dapat berupa tes lisan, maupun tertulis (Nuriyah, 2014). Setiap guru diberikan kebebasan untuk memilih alat tes yang digunakan dalam proses evaluasi.

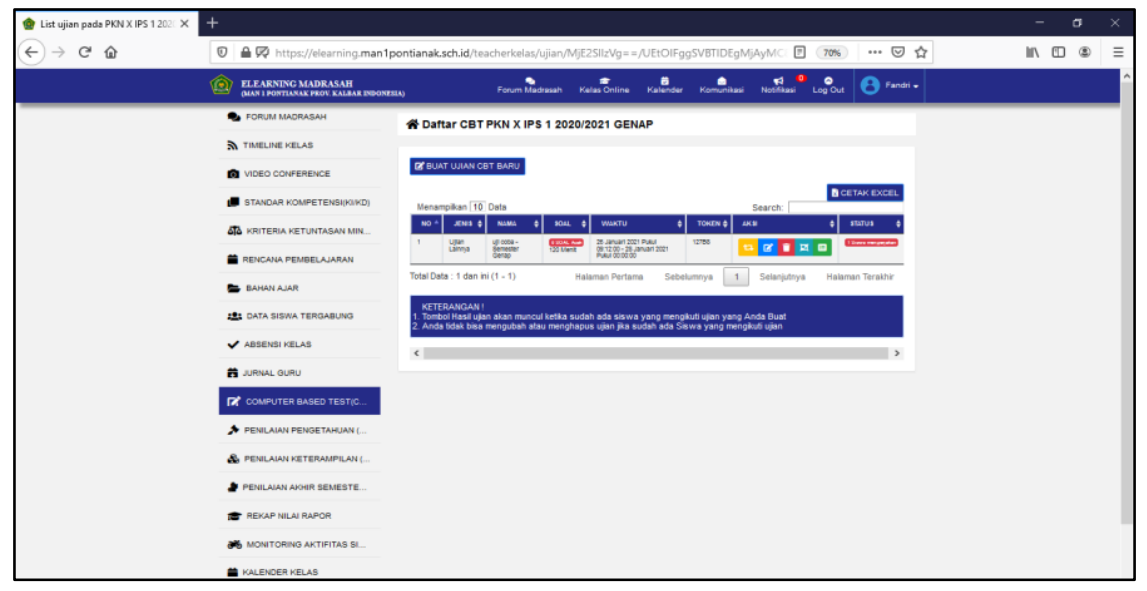

Gambar 3. Fitur Computer Based Tes (CBT)

Page 538 of 542 
Gambar 3 di atas merupakan fitur Computer Based Tes (CBT) yang dapat digunakan oleh guru di aplikasi E-learning Madrasah. berdasarkan wawancara yang dilakukan kepada guru mengatakan untuk melakukan penilaian E-learning telah menyediakan menu CBT (Computer Base Tes) yang dapat digunakan guru dalam pemberian penilaian baik tugas harian maupun ulangan harian. Selain itu terdapat fitur penilaian keterampilan untuk guru menilai psikomotorik siswa. Wawancara yang dilakukan kepada siswa mengatakan bahwa E-learning Madrasah terdapat menu CBT untuk mengerjakan tugas-tugas.

Pelaksanaan Evaluasi pembelajaran di MAN 1 Pontianak dilakukan dengan aplikasi Elearning Madrasah. E-learning Madrasah menyediakan menu untuk melakukan evaluasi, baik kognitif, afektif, maupun psikomotorik. Peniliaan kognitif atau pengetahuan (K3), guru dapat membuat dalam bentuk Tes. Tes merupakan serangkaiaan tugas atau soal-soal yang harus diselesaikan atau dikerjakan oleh siswa (Arifin, 2012). Bentuk tes yang disediakan E-learning Madrasah bervariasi, ada yang pilihan ganda, kuis, essay, menjodohkan, dan benar salah. Guru bebas untuk melakuan tes dalam bentuk apa saya yang diinginkan dan disesuaikan dengan kemampuan. Guru dapat membuat tes yang akan diberikan melalui menu Computer Based Test (CBT). Melalui menu tersebut, guru dapat mengatur waktu siswa mengerjakan, mengatur kapan bisa dibuka, membuat soal serta kunci jawaban, dan jika siswa telah mengerjakan, guru dapat langsung merekap nilai yang secara otomatis sudah terhitung. Semua bentuk tugas yang dibeirkan akan secara otomatis tersusun di menu Penilaian Pengetahuan (K3). Siswa dapat mengakses menu Penilaian pengetahuan, dan mengerjakan tugas yang ada sesuai waktu yang sudah diatur. Pengerjaan tugas evaluasi yang diberikan siswa harus memiliki kemampuan dalam mengola bergamnya informasi yang tersedia di internet, hal yang paling penting dilakukan siswa adalah mengecek kredibilitas sumber dan mencocokan hasilnya dengan pendapatnya (Chiu et al., 2013).

Untuk penilaian afektif atau sikap, setiap guru dapat menulis dalam menu jurnal guru dalam tiap pertemuan. Guru hanya memilih tambah kejadian pada menu jurnal guru, kemudian mengisi form yang sudah disediakan. Penilaian sikap atau afektif dimenu jurnal guru ini akan secara otomatis akan masuk pada akun Guru Bimbingan Konseling. Untuk tindak lanjutnya disini peran guru BK akan menangani siswa yang direkap oleh guru pada menu jurnal guru. Oleh sebab itu untuk tercapainya hasil evaluasi yang dilakukan dalam menggunakan apliksi E-Learning Madrasah ini juga dipengaruhi oleh lingkungan rumah yang baik termasuklah peran orang tua di rumah (Mora \& Escardíbul, 2018).

Penilaian psikomotorik atau keterampilan (K4) guru bisa langsung membuat di menu penilaian keterampilan di E-learning Madrasah. Setiap Kompetensi Dasar minimal dilakukan satukali penilaian psikomotorik atau keterampilan. Penilaian keterampilan dapat perupa praktik, proyek, produk, atau portofolio. Pada menu penilaiaan keterampilan, guru memilih menu buat penilaian, kemudian mengisi form yang sudah ada, dimulai dari skema penilaiaan, bentuk penilaiaan, KD yang dinilai, waktu pengerjaan, batas waktu pengumpulan dan keterangan pengerjaan. Siswa dapat mengakses langsung di menu Penilaian Keterampilan sesuai dengan waktu pengerjaan dan waktu pengumpulan jika guru sudah membuat penilaiaannya. Jika siswa sudah mengumpulkan tugasnya dalam bentuk upload file, guru dapat melihatnya dan langsung dapat memberikan penilaiaan. Tugas berikutnya yang dilakukan oleh guru adalah memberiakan penilaian dari tugas yang dikerjakan oleh siswa. Penilaian termasuk salah satu tugas yang sulit karena yang dilihat bukan semata hasil akhirnya namun yang paling penting adalah guru harus mampu mengamati dan memahami perilaku, kinerja, dan kemajuan anak didiknya. Ketika proses pembelajaran didukung oleh sistem Technology Enhanced Learning (TEL), maka wajib mengetahui apa yang diamati dan bagaimana memahami serta menganalisisnya (Djouad \& Mille, 2018).

Evaluasi pembelajaran dalam aplikasi E-learning Madrasah pelaksanaannya dapat dilakukan pada setiap pertemuan dengan memberikan tugas, ada juga yang tidak. Bentuk evaluasi yang digunakan mayoritas dalam bentuk pilihan ganda, walupun menu lainnya juga tersedia yang bisa digunakan oleh guru. E-learning juga membantu guru dalam mengoreksi tugas ataupun evaluasi 
lainnya yang diberikan. Siswa dengan menu CBT yang terdapat di E-learning Madrasah dapat melihat tugas-tugas yang diberikan, dan juga terdapat batas waktu pengerjaan. Untuk Penilaiaan Tengah Semester dan Penilaiaan Akhir Tahun atau dikenal selama ini dengan ulangan umum, dapat dilakukan dengan E-learning Madrasah. Dengan adanya menu CBT mempermudah guru dan siswa untuk melaksanakan evaluasi pembelajaran.

\section{SIMPULAN}

Agar pembelajaran daring pada masa pandemic covid-19 tetap berjalan secara efektif dan efisien, kementerian agama mengeluarkan aplikasi E-learning Madrasah. Hadirnya E-learning Madrasah memberi warna baru dalam dunia pendidikan di era industry 4.0 ini terutama pada saat pandemi covid-19. Peran E-learning Madarasah di Madrasah Aliyah Negeri 1 Pontianak sangat diutamakan dalam pembelajaran daring dimulai dari perencanaan, pelaksanaan, dan evaluasi pembelajaran.

Perencanaan pembelajaran menggunakan E-learning Madrasah di Madrasah Aliyah Negeri 1 Pontianak sangat membantu guru dalam merancang sebuah perencanaan dalam pembelajaran. Guru dapat langsung menyusun perencanaan di E-learning Madrasah dengan menu yang telah disediakan. E-learning Madrasah secara otomatis akan menyimpan data-data perencanaan yang guru susun, dan jika diperlukan untuk dicetak, guru dapat langsung mencetak dengan menu yang ada. Naskah perencanaan pembelajaran yang tersusun oleh sistem E-learning Madrasah sudah menyesuaikan dengan kebutuan guru saat ini. Pelaksanaan pembelajaran masa pandemi covid-19, E-learning Madrasah menjadi solusi bagi guru dan siswa untuk melakukan aktivitas pembelajaran. Dilengkapi dengan menu video converensi, guru dan siswa dapat melakukan pertemuan virtual. Siswa juga dapat membaca materi yang diberikan dimenu bahan ajar. Walaupun tidak melalui video virtual, guru dapat melihat aktivitas yang dilakukan dari notivikasi yang diberikan, serta absensi online guru dapat langsung melihat kehadiran siswa. Dengan demikian, E-Learning Madrasah memberikan solusi dalam melakukan proses pembelajaran online. Tahap akhir dalam pembelajaran adalah evaluasi, atau proses penilaiaan dari hasil pembelajaran yang dilakukan. Evaluasi pembelajaran secara online ini, E-learning Madrasah menyediakan menu-menu untuk melakukan penilaiaan. Penilaiaan kognitif dapat dilakukan dalam bentuk pilihan ganda, essay, benar salah, menconcokkan yang dapat dilakukan di menu Computer Based Tes (CBT). Guru dapat langsung mengisi dalam bentuk soal yang diinginkan dan mengatur waktu pelaksanaan evaluasi, sehingga siswa dapat melihat jadwal pelaksanaan evaluasinya tersebut. Untuk penilaan sikap atau afektif, guru dapat mengisi jurnal kelas. Jurnal kelas diisi guru jika terdapat siswa melakukan kegiatan yang positif maupun negatif. Jurnal kelas tersebut langsung tertuju kepada guru Bimbingan Konseling untuk ditindaklanjuti. Untuk penilaiaan Keterampilan dalam bentuk portofolio, proyek, dan praktik dapat dilakukan dimenu penilaiaan Keterampilan. Guru dapat langsung memberikan tugas yang diinginkan, dan siswa dapat melihat intruksi tersebut dan mengupload tugasnya.

Penelitan ini masih memiliki keterbatasan yakni hanya pada deskripsi bagaimana perencanaan, pelaksanaan, dan evaluasi pembelajaran menggunakan E-learning Madrasah. Penelitian ini dapat digunakan sebagai bahan pengembangan penelitian selanjutnya yakni pengembangan pengunaan fitur aplikasi E-learning Madrasah agar lebih baik lagi.

\section{DAFTAR PUSTAKA}

Ananda, R. (2019). Perencanaan Pembelajaran. Lembaga Peduli Pengembangan Pendidikan Indonesia (LPPPI): Medan.

Andrian, Y., \& Rusman, R. (2019). Implementasi pembelajaran abad 21 dalam kurikulum 2013. Jurnal Penelitian Ilmu Pendidikan, 12(1), 14-23. https://doi.org/10.21831/jpipfip.v12i1.20116

Anggraeni, P., \& Akbar, A. (2018). Kesesuaian Rencana Pelaksanaan Pembelajaran Dan Proses Pembelajaran. Jurnal Pesona Dasar, 6(2), 55-65. https://doi.org/10.24815/pear.v6i2.12197

Arifin, Z. (2012). Evaluasi pembelajaran. Direktorat Jendral Pendidikan Isalam Kementerian Agama RI: Jakarta. 
Boca, D. Del, Boca, D. Del, \& Rossi, M. C. (2020). Women's Work, Housework and Childcare, before and during Covid-19. IZA - Institute of Labor Economic. IZA DP No. 13409

Bonal, X., \& González, S. (2020). The impact of lockdown on the learning gap: family and school divisions in times of crisis. International Review of Education, 66(5-6), 635-655. https://doi.org/10.1007/s11159-020-09860-z

Chien, T. (2012). Computer self efficacy and factors influencing e-learning effectiveness. European Journal of Training and Development, 36(7), 670-686. https://doi.org/10.1108/03090591211255539

Chiu, Y. L., Liang, J. C., \& Tsai, C. C. (2013). Internet-specific epistemic beliefs and self-regulated learning in online academic information searching. Metacognition and Learning, 8(3), 235-260. https://doi.org/10.1007/s11409-013-9103-x

Djouad, T., \& Mille, A. (2018). Observing and Understanding an Online Learning Activity: A ModelBased Approach for Activity Indicator Engineering. Technology, Knowledge and Learning, 23(1), 41-64. https://doi.org/10.1007/s10758-017-9337-9

Edmunds, J. A., Gicheva, D., Thrift, B., \& Hull, M. (2021). High tech, high touch: The impact of an online course intervention on academic performance and persistence in higher education. Internet and Higher Education, 49, 100790. https://doi.org/10.1016/j.iheduc.2020.100790

Fauzi, A., Baharun, H., Mundiri, A., \& Manshur, U. (2018). E-Learning in Pesantren : Learning Transformation based on the Value of Pesantren E-Learning in Pesantren: Learning Transformation based on the Value of Pesantren.

Firman, F., \& Rahayu, S. (2020). Pembelajaran Online di Tengah Pandemi Covid-19. Indonesian Journal of Educational Science (IJES), 2(2), 81-89. https://doi.org/10.31605/ijes.v2i2.659

Hanum, N. S. (2013). Keefektifan E-Learning Sebagai Media Pembelajaran ( Studi Evaluasi Model Pembelajaran E-Learning Smk Telkom Sandhy Putra Purwokerto ) The Effectiveness Of ELearning As Instructional Media ( Evaluation Study Of E-Learning Instructional Model Insmk Telkom Sandhy Putra. 3, 90-102.

Hikmah, S. (2020). Pemanfaatan e-learning Madrasah dalam Pelaksanaan Pembelajaran Jarak Jauh Masa Pandemi di MIN 1 Rembang. Edutrained: Jurnal Pendidikan Dan Pelatihan, 4(2), 73-85.

Insiyah, S. J. (2020). E- Learning Madrasah Dan Solusi Pembelajaran Di Tengah-Tengah Pandemi Covid-19. Khazanah: Jurnal Edukasi, 2(2), 139-147.

Kuhfeld, M., Soland, J., Tarasawa, B., Johnson, A., Ruzek, E., \& Liu, J. (2020a). Projecting the Potential Impact of COVID-19 School Closures on Academic Achievement. Educational Researcher, 49(8), 549-565. https://doi.org/10.3102/0013189X20965918

Kuhfeld, M., Soland, J., Tarasawa, B., Johnson, A., Ruzek, E., \& Liu, J. (2020b). Projecting the potential impacts of COVID-19 school closures on academic achievement Executive Vice President of Research , NWEA. 20,1-17. https://doi.org/10.26300/cdrv-yw05

Lubis, M., Yusri, D., \& Gusman, M. (2020). Pembelajaran Pendidikan Agama Islam Berbasis ELearning (Studi Inovasi Pendidik MTS. PAI Medan di Tengah Wabah Covid-19). Fitrah: Journal of Islamic Education, 1(1). https://doi.org/http://jurnal.staisumateramedan.ac.id/index.php/fitrah/article/view/1

Mazid, S., \& Suharno, S. (2019). Implementasi nilai-nilai multikultural dalam pembelajaran PKn. Harmoni Sosial: Jurnal Pendidikan IPS, 6(1), 72-85. https://doi.org/10.21831/hsjpi.v6i1.10248

Miles, M. ., \& Huberman, A. M. (1984). Qualitative data analysis: An expanded.

Moleong, L. J. (2017). Metode Penelitian Kualitatif. PT. Remaja Rosdakarya Offset (cetakan ke-36).

Mora, T., \& Escardíbul, J. O. (2018). Home Environment and Parental Involvement in Homework During Adolescence in Catalonia (Spain). Youth and Society, 50(2), 183-203. https://doi.org/10.1177/0044118X15626050

Muali, C., Islam, S., Bali, M. E. I., Hefniy, Fauzi, H. B., Mundiri, A., Jasri, M., \& Fauzi, A. (2018). Free Online Learning Based On Rich Internet Applications; The Experimentation Of Critical Thinking About Student Learning Style Free Online Learning Based On Rich Internet Applications; The Experimentation Of Critical Thinking About Student Learning Sty. IOP 
Conf. Series: Journal of Physics: Conf. Series 1114, 1-6. https://doi.org/doi :10.1088/1742$6596 / 1114 / 1 / 012024$

Munif, M., Umiarso, Mardia, Laili, N., Sa'dia, H., \& Muhid. (2021). Integration of Distance Learning Design and e-Learning in Madrasah. Journal of Physics: Conference Series PAPER, 1-6. https://doi.org/10.1088/1742-6596/1779/1/012070

Mustajab, Baharun, H., \& Fawa'iedah, Z. (2020). Adapting to Teaching and Learning During Covid19: A Case of Islamic School's Initiative of Self-regulated. 14(2), 241-264. https://doi.org/10.22437/bio.v6i2.9759.3

Nawawi, H. (2007). Metode penelitian Bidang Sosial. Gadjah Mada University Press.

Nuriyah, N. (2014). Evaluasi pembelajaran: sebuah kajian teori. Jurnal Edueksos, III(1), 73-86.

Persada, Y. I., Djatmika, E. T., \& Degeng, I. N. S. (2020). Pelaksanaan Pendekatan Scientific Dalam Pembelajaran Tematik. Jurnal Pendidikan: Teori, Penelitian, Dan Pengembangan, 5(1), 114 120.

Puška, A., Puška, E., Dragić, L., Maksimović, A., \& Osmanović, N. (2021). Students' Satisfaction with E-learning Platforms in Bosnia and Herzegovina. Technology, Knowledge and Learning, 26(1), 173-191. https://doi.org/10.1007/s10758-020-09446-6

Putria, H., Maula, L. H., \& Uswatun, D. A. (2020). Analisis Proses Pembelajaran dalam Jaringan (DARING) Masa Pandemi Covid- 19 Pada Guru Sekolah Dasar. Jurnal Basicedu, 4(4), 861870. https://doi.org/10.31004/basicedu.v4i4.460

Ratnawulan, E. H. A. R. (2014). Evaluasi Pembelajaran. Pustaka Setia Bandung.

Rigianti, H. A. (2020). Kendala Pembelajaran Daring Guru Sekolah Dasar Di Kabupaten Banjarnegara. Elementary School, 7(2), 297-301.

Sadikin, A., \& Hamidah, A. (2020). Pembelajaran Daring di Tengah Wabah Covid-19. Biodik, 6(2), 109-119. https://doi.org/10.22437/bio.v6i2.9759

Setemen, K. (2010). Pengembangan evaluasi pembelajaran online. Jurnal Pendidikan Dan Pengejaran, 43(3), 207-214.

Setiawan, F. (2013). Kemampuan Guru Melakukan Penilaian Dalam Pembelajaran Melalui Internalisasi Nilai Kejujuran Pada Pembelajaran Pendidikan Kewarganegaraan. Jupiis: Jurnal Pendidikan Ilmu-Ilmu Sosial, 5(2), 73-81. https://doi.org/10.24114/jupiis.v5i2.1116

Sutini, S., Mushofan, M., Ilmia, A., Yanti, A. D., Rizky, A. N., \& Lailiyah, S. (2020). Efektivitas Pembelajaran Daring dengan Menggunakan E-learning Madrasah Terhadap Optimalisasi Pemahaman Matematika Siswa. JRPM (Jurnal Review Pembelajaran Matematika), 5(2), 124 136. https://doi.org/10.15642/jrpm.2020.5.2.124-136

Yuliana. (2020). Corona virus diseases (Covid-19); Sebuah tinjauan literatur. Wellness and Healthy Magazine, 2(February), 187-192. https://doi.org/10.30604/well.95212020 